UDC 541.64:678.7

\title{
ZINC-CONTAINING NANOCOMPOSITES ON THE BASIS OF HIGH PRESSURE POLYETHYLENE
}

\author{
T.M.Guliyeva \\ Institute of Polymer Materials, NAS of Azerbaijan \\ turkanquliyeva30@gmail.com \\ Received 27.05.2019 \\ Accepted 10.10.2019
}

\begin{abstract}
The effect of nanofiller additives containing nanoparticles of zinc oxide stabilized by a polymer matrix of maleinated polyethylene, obtained by a mechanochemical method, on the properties of composites based on high-pressure polyethylene was studied by X-ray phase and thermographic analyzes. The improvement of the strength, deformation and rheological parameters, as well as the thermo-oxidative stability of the obtained nanocomposites was revealed, which is apparently due to the synergistic effect of the interaction of zinc-containing nanoparticles with maleic maleinated polyethylene groups. It is shown that polyethylene based nanocomposites can be processed both by pressing and by injection molding and extrusion, which expands its application field.
\end{abstract}

Keywords: polyethylene, zinc-containing nanofillers, maleinized polyethylene, physicol - mechanical properties, $X$-ray phase and thermographic analyzes.

\section{doi.org/10.32737/0005-2531-2020-2-34-38}

\section{Introduction}

The development of the science of nanoscale and cluster metal-containing particles in polymer matrices is stimulated by the evergrowing interest in this problem in many areas of chemistry, physics and materials science. The development of such research has largely contributed to the creation of metal-polymer composite materials with specific physicomechanical and operational properties: increased thermal and electrical conductivity, high magnetic susceptibility, ability to shield ionizing radiation [1-7].

The use of nanoparticles of $d$-valence metals (zinc, copper, cobalt, nickel etc.) in polymers makes it possible to obtain fundamentally new materials which are widely used in radio and optoelectronics as magnetic, electrically conductive and optical media $[4,7]$.

It is known that fillers in the amount of 30-50 mass\% are used to improve the performance of plastics. Filled plastics are mainly used as a construction material [8].

In the world today, various types of polymer composites based on nanofillers actively replace traditional materials [9].

Polymer nanocomposites can be obtained in situ, i.e. by polymerization of the monomer in the presence of a nanofiller previously dispersed in the reaction medium [10]. The method of introducing a nanofiller in a polymer melt is more preferable. This method is most convenient for use in modern industry, it is polymers to a wide range of manufacturers, which makes this method promising and cost-effective [11].

Modification of polyethylene (PE) by creating various composite materials can significantly expand the scope of its application. Filled polyethylene takes one of the first places among filled thermoplastics. Currently, more and more attention is paid to the development of composites with nanoscale fillers.

Such composite materials have improved properties than composite materials with microand macrofillers. The introduction of even a small amount of nanosized filler into polyethylene can significantly improve physical properties, improve barrier qualities, increase heat resistance, electrical conductivity etc. [7, 11].

The present work is devoted to the preparation and study of the properties of nanocomposites based on high-pressure polyethylene using metal-containing nanoparticles stabilized by a polymer matrix as a nanofiller.

\section{Experimental part}

In the work were used: high-pressure polyethylene brand 15803-020 (PE) - "SOCAR", 
Azerbaijan, zinc-containing nanoparticles (NP) stabilized on a polymeric matrix were used as a nanofiller.

Nanofiller (NF) contains zinc-containing nanoparticles stabilized on an (MPE) matrix (maleized high-pressure polyethylene) and obtained by a mechanochemical method in a polymer melt. The content of nanoparticles is 5.0 mass $\%$, size $34-37 \mathrm{~nm}$, degree of crystallinity $25-45 \%[12,13]$.

Nanocomposite polymeric materials were obtained by mixing PE with a zinc-containing nanofiller on laboratory rolls at a temperature of $130-135^{\circ} \mathrm{C}$ for 15 minutes. For mechanical testing, the mixtures were pressed in the form of plates with a thickness of $1 \mathrm{~mm}$ at $170^{\circ} \mathrm{C}$ and a pressure of $10 \mathrm{MPa}$ for 10 minutes.

Physico-mechanical properties of the obtained compositions were determined on the device RMI-250.

The melt yield point (MYP) was determined on a CEASTMF50 capillary rheometer by INSTRON, Italy at a temperature of $190^{\circ} \mathrm{C}$ and a load of $5 \mathrm{~kg}$.

$\mathrm{X}$-ray phase analysis (XRD) of the obtained compositions was carried out on the device "D2 Phaser" by Bruker (Germany).

The thermal stability of the studied samples of nanocomposites was studied on a Q$1500 \mathrm{D}$ derivatograph by MOM, Hungary. The tests were carried out in an air atmosphere in a dynamic mode under heating the sample at 5 gram/min from 20 to $500^{\circ} \mathrm{C}$, charge $100 \mathrm{mg}$, the sensitivity of the DTA channels $-250 \mu \mathrm{V}$, TG100, DTG-1 mV.

\section{Results and discussion}

Nanocomposite polymer materials based on MPE with zinc-containing nanofiller are obtained. The ratio of initial components (mass $\%): \mathrm{PE} / \mathrm{NF}=100 /(0,0.3,0.5,1.0)$.

The physico-mechanical, rheological, thermophysical, and thermal properties of the obtained nanocomposites were studied.

Table 1 presents the physico-mechanical and rheological parameters of the obtained composite materials.

As can be seen from the data of Table 1, the introduction of $0.3-0.5$ mass $\% \mathrm{NF}$ to the composition leads to an increase in the strength index from 11.39 to $13.56 \mathrm{MPa}$.

Table 1. Physico-mechanical and rheological parameters of the obtained nanocomposites

\begin{tabular}{|c|c|c|c|c|}
\hline 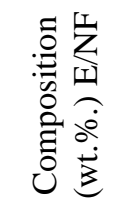 & 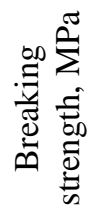 & 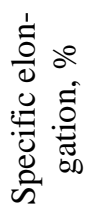 & 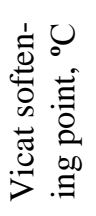 & 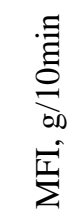 \\
\hline $100 / 0$ & 11.39 & 400 & 130 & 9.9 \\
\hline $100 / 0.3$ & 12.07 & 720 & 140 & 10.8 \\
\hline $100 / 0.5$ & 13.56 & 660 & 135 & 11.7 \\
\hline $100 / 1.0$ & 11.67 & 637 & 128 & 15.4 \\
\hline
\end{tabular}

An increase in the NF concentration of more than 0.5 mass\% leads to a decrease in the strength of the composite $(11.67 \mathrm{MPa})$, which is probably due to the aggregation of nanoparticles, leading to the formation of microdefects in the bulk of the polymer matrix. An increase in the concentration of NF leads to an increase in the rapture strain of the composite by $1.6-1.8$ times, which is apparently due to the synergistic effect associated with the presence of zinccontaining nanoparticles on the MPE matrix containing maleic groups, the mutual influence of which increases as the strain value and strength index. The study of Vicat softening point obtained compositions showed that the introduction of nanofiller into the composition of PE leads to an increase in heat resistance from 130 to $140^{\circ} \mathrm{C}$. At the same time, the introduction of 0.3 mass \% NF leads to an increase in the heat resistance index to $140^{\circ} \mathrm{C}$, a further increase in the amount of NF leads to a decrease in the heat resistance index, which is probably due to microdefects in the obtained composite. At the same time, an increase in the content of nanofiller (0.5-1.0 mass\%) Increases the melt flow rate (MFR) to 11.7 (0.5 mass\%) and 15.4 (1.0 mass\%) g/10 min, which indicates an improvement in the fluidity of the composition and the possibility of processing it by injection molding and extrusion.

Figures 1 and 2 show the XRD diffractograms of the initial PE and PE with a zinccontaining nanofiller. Reflexes corresponding to the original PE: $d_{\mathrm{hkl}} 4.46424,4.11616,3.72300$, $2.46971 \AA$ (Figure 1) and reflexes characteristic 
of zinc-containing nanoparticles: $d_{\mathrm{hkl}} \quad 2.82226$; $2.61320 ; 2.47316 ; 1.90934 ; 1.62297 ; 1.37822 \AA$ (Figure 2) are shown, which corresponds to the $d_{\mathrm{hkl}}$ zinc oxide series in the ASTM card file. [dSpacings (20) - 01-071-3645 (Fixed Slit Intensity) - $\mathrm{Cu}_{\alpha 1} 1.54056 \AA$. Entry Date:
11/19/2008, Last Modification Date: 01/19/2011]. Figures 1, 2 are interpreted: the size of the nanoparticles does not change, the degree of crystallinity changes slightly: for PE $=53.2$, for $\mathrm{PE} / \mathrm{NP} \mathrm{ZnO} \mathrm{MPE}=50.1$.

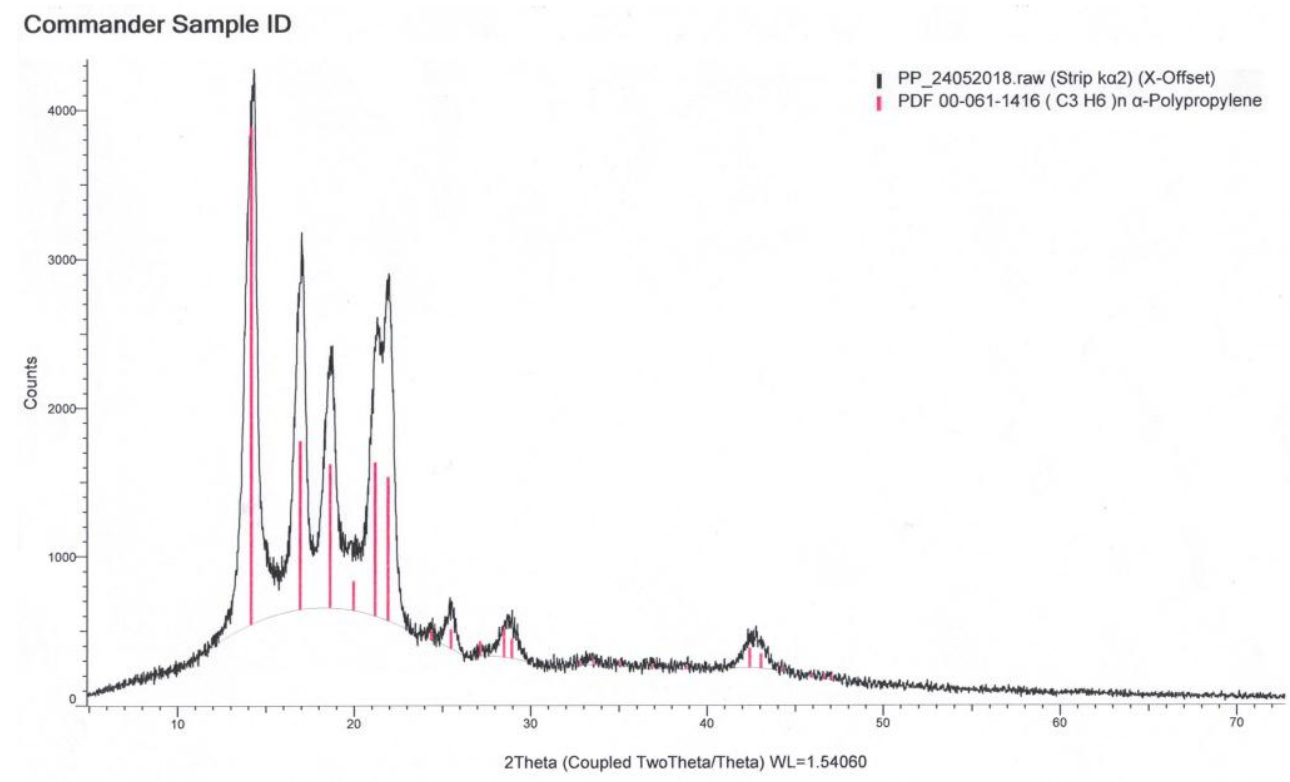

Fig.1. Diffractogram of the original PE.

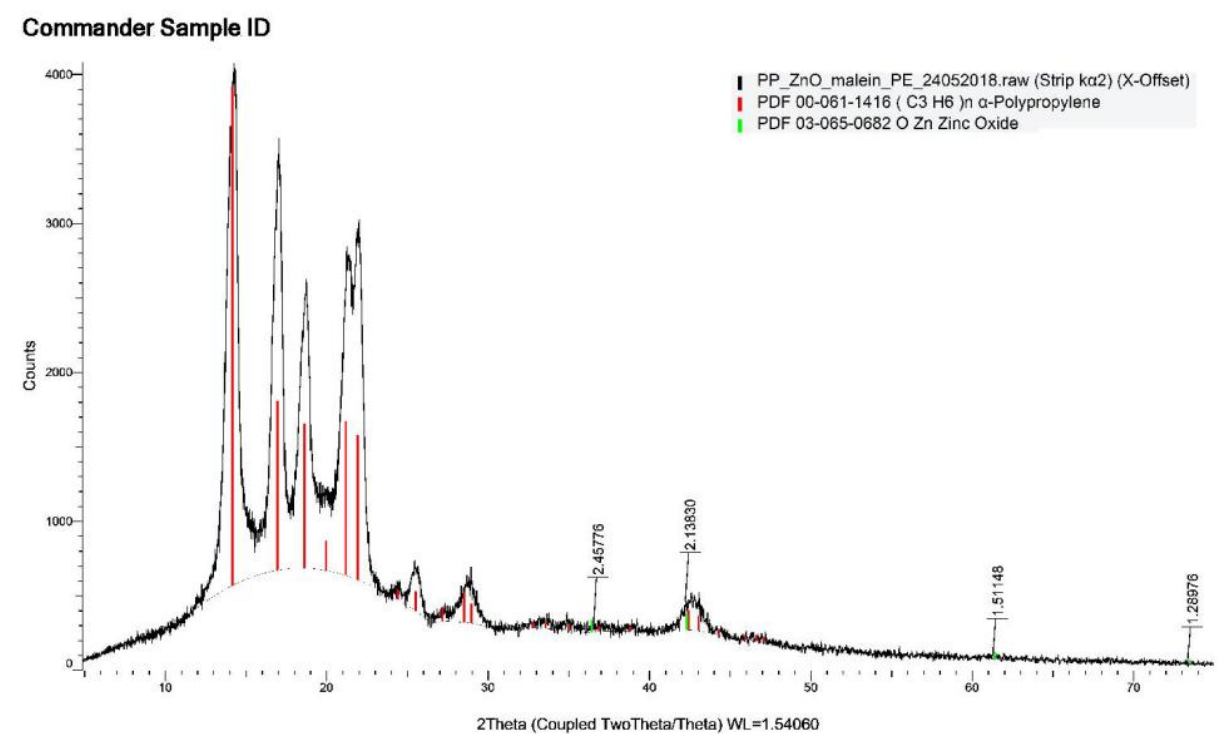

Fig.2. Diffractogram of PE with zinc-containing nanofiller. 
Thermal stability of the studied samples based on PE containing NF with zinc oxide nanoparticles was estimated by the mass loss, activation energy $\left(E_{\mathrm{a}}\right)$ of thermo-oxidative destruction calculated by double logarithmization using the TG curve according to the method [14], by the temperatures of $10 \%\left(T_{10}\right), 20 \%$ $\left(T_{20}\right)$ and $50 \%\left(T_{50}\right)$ decay of the studied samples, as well as by the time of their half-life time $-\tau_{1 / 2}$. The resulting derivatographic research data are shown in Table 2.

Table 2. Thermal properties of the studied samples of nanocomposites

\begin{tabular}{|c|c|c|c|c|c|}
\hline $\begin{array}{c}\text { Composition } \\
\text { (maas \%.) PE/NF }\end{array}$ & $\begin{array}{c}T_{10}, \\
\%\end{array}$ & $\begin{array}{c}T_{20}, \\
\%\end{array}$ & $\begin{array}{c}T_{50}, \\
\%\end{array}$ & $\begin{array}{c}\tau_{1 / 2}, \\
\mathrm{~min}\end{array}$ & $\begin{array}{c}E_{\mathrm{a},} \\
\mathrm{kJ} / \mathrm{mol}\end{array}$ \\
\hline $100 / 0$ & 325 & 360 & 400 & 72 & 120.4 \\
\hline $100 / 0.3$ & 340 & 365 & 425 & 75 & 130.8 \\
\hline $100 / 0.5$ & 360 & 370 & 450 & 81 & 135.9 \\
\hline $100 / 1.0$ & 337 & 360 & 420 & 74 & 132.7 \\
\hline
\end{tabular}

It is shown that the introduction of NF containing copper NP into the composition contributes to an increase in the half-life temperature of the samples: $T_{50}$ from 400 to $450^{\circ} \mathrm{C}$; the half-life time $\tau_{1 / 2}$ increases from 72 to $81 \mathrm{~min}$., the activation energy $\left(E_{\mathrm{a}}\right)$ of thermal-oxidative of the obtained nanocomposites rises from 120.4 to $135.9 \mathrm{~kJ} / \mathrm{mol}$.

Derivatographic studies have shown that the introduction of NF containing zinc oxide nanoparticles into the composition improves the thermal oxidative stability of the obtained nanocomposites.

Numerous experimental data on the mechanical, strength, relaxation, and other properties of polymer - polymer blends and polymer - filler mixtures are explained in the context of perceptions about the presence of an interfacial layer [15].

The properties of polymer composites are markedly influenced by the supramolecular structure of the polymer (the size of spherulites, the degree of crystallinity, the presence of $\mathrm{C}=$ $\mathrm{O}$ groups and different branchings etc.) and the interfacial interaction at the interface.

The metal-containing nanoparticles used in the work, being located on the boundary of the interfacial layer of the structural elements of PE and MPE, contribute to the formation of heterogeneous nucleation centers in the melt, which during the stepwise cooling of the nanocomposite contribute to an overall improvement of the crystallization process and the formation of a relatively fine spherulitic structure.

The results obtained indicate that small amounts of nanofiller (0.3-0.5 mass \%) introduced into the polymer obviously play the role of structure-forming agents - artificial crystallization nuclei, that contributes to the formation of a fine- spherulitic structure in the polymer, which is characterized by improved physicomechanical, rheological and thermal properties of the obtained nanocomposite [8].

\section{Summary}

The effect of a nanofiller containing zinc oxide nanoparticles, stabilized by a matrix of maleinized MPE polyethylene, obtained by a mechano-chemical method, on the properties of PE-based composites was studied.

XRD diffractograms confirm the presence of zinc oxide nanoparticles on the PE matrix.

The improvement of the strength, deformation and rheological parameters, as well as the thermo-oxidative stability of the obtained nanocomposites was revealed, which is apparently due to the synergistic effect of the interaction of zinc-containing nanoparticles with maleic MPE groups.

It is shown that nanocomposites based on PE can be processed by pressing as well as by injection molding and extrusion.

A promising use of a nanofiller as an additive to PE, containing zinc oxide nanoparticles, stabilized by a maleinated polyethylene matrix, obtained by a mechanochemical method is shown, which contributes to the creation of a fine-crystalline structure of the composition, is shown, herewith its properties are improved, thereby expanding the field of application of the obtained nanocomposite.

\section{References}

1. Joseph H. Koo. Polymer nanocomposites. Processing, characterization and applications. New York: McGraw-Hill. Nanoscience and Technology Series. 2006. 289 p. 
2. Suzdalev I.P., Suzdalev P.I. Nanoclastery i nanoclasternye sistemy. Uspehi himii. 2001. T. 70. No 3. S. 203-240.

3. Pomogailo A.D. Gibridnye polimer - -neorganicheskie nanokompozity. Uspehi himii. 2000. T. 6. No 1. S. 60-89.

4. Pomogailo A.D., Rozenberg A.S., Ufliand I.E. Nanochastitcy metallov v polimerakh. M.: Himiia, 2000. $672 \mathrm{~s}$.

5. Tretiakov A.O. Polimernye nanokompozity materialy XXI veka. Oborudovanie i instrumenty dlia professionalov. 2003. V. 37. No 2. S. 18-20.

6. Mihailin Iu.A. Polimernye nanokompozitcionnye materialy. Polimernye materialy. 2009. No 7. S. 10-13.

7. Gubin S.P., Yurkov G.Yu., Kosobudsky I.D. Nanomaterials вased on metal-containing nanoparticles in polyethylene and other carbon-chain polimers. International Journal of Materials and Product Technology. 2005. V. 23. No 1-2. P. 2-25.

8. Entciclopediia polimerov. M.: Sovet. Entciclopediia. 1974. T. 2. S. 328.

9. Foster L. Nanotekhnologii. Nauka, innovatcii i vozmozhnosti. M.: Tekhnosfera. 2008. 352 s.

10. Antipov E.M., Guseva M.A., Gerasin V.A., Korolyov Iu.M., Rebrov A.V., Fischer H.R., Razumov- skaia I.V. Struktura i deformatcionnoe povedenie nanokompozitov na osnove PE $\mathrm{i}$ modifitcirovannykh glin. Vysokomol. soed. 2003. A. T. 45. № 11. S. 1874-1884.

11. Savinova M.E., Semenova E.S., Sokolova M.D. Issledovanie fiziko-mehanicheskikh svoistv $\mathrm{PE}$ 80B, modifitcirovannogo nanoshpineliu magniia i tceolitami. Elektr. nauchn. zhurn. Neftegazovoe delo. 2011. No 6. S. 328-333.

12. Kurbanova N.I., Aliyev A.T., Guliyeva T.M., Ragimova C.K., Axmadbekova C.F., Ishenko N.Y., Nurullayeva D.R. Metal-containing nanoparticles in maleinized polyethylene matrix. PolyChar 26 World Forum on Advanced Materials. Georgiya. 2018. Tbilisi. P. 59.

13. Guliyeva T.M., Kurbanova N.I. Obtaining and study of the structure and properties of metalcontaining nanoparticles in the matrix of maleinized polyethylene. Genc tedqiqatchi. 2019. № 4. P. 32-37

14. Praktikum po himii i fizike polimerov. Pod red. V.F.Kurenkova. M.: Himiia, 1990. 299 s.

15. Pomogailo A.D. Molekuliarnye polimer-polimernye kompozitcii. Sinteticheskie aspekty. Uspehi himii. 2002. T. 71. No 1. S. 5-38.

\section{YÜKSЭK TəZYIQQ POLIETILENI əSASINDA SINK TəRKIBLİ NANOKOMPOZITLəR}

\section{T.M.Quliyeva}

Tərkibində maleinləşdirilmiş polietilen matrisində stabilləşdirilmiş sink oksid nanohissəcikləri saxlayan nanodoldurucuların yüksək təzyiq polietilen əsasında mexaniki-kimyəvi üsulla alınmış nanokompozitlərin xassələrinə təsiri rentgenfaza və termoqravimetrik analiz metodları ilə tədqiq olunmuşdur. Alınan nanokompozitlərin möhkəmlik, defarmasion və reoloji göstəricilərinin həmçinin termooksidləşmə stabilliyinin yaxşılaşması aşkar edilmişdir. Bu da sinktərkibli nanohissəciklərin maleinləşdirilmiş polietilennin malein qrupları ilə qarşılıqlı təsirinin sinergetik effekti ilə izah oluna bilər. Göstərilmişdir ki. polietilen əsaslı nanokompozitlər həm pressləmə həm də yüksək təzyiq altında tökmə və ekstruziya üsulları ilə emal oluna bilər ki, bu da onların tətbiqi imkanlarını genişləndirir.

Açar sözlor: polietilen, sinktərkibli nanodoldurucular, maleinləşdirilmiş polietilen, fiziki-mexaniki xassəlar, rentgenfaza va termoqravimetrik analizlar.

\section{ЦИНКСОДЕРЖАЩИЕ НАНОКОМПОЗИТЫ НА ОСНОВЕ ПОЛИЭТИЛЕНА ВЫСОКОГО ДАВЛЕНИЯ}

\section{Т.М.Гулиева}

Исследовано влияние добавок нанонаполнителей, содержащих наночастицы оксида цинка, стабилизированные полимерной матрицей малеинизированного полиэтилена, полученные механохимическим методом, на особенности свойств композитов на основе полиэтилена высокого давления методами рентгенофазового и термографического анализов. Выявлено улучшение прочностных, деформационных и реологических показателей, а также термоокислительной стабильности полученных нанокомпозитов что, по-видимому, связано с синергетическим эффектом взаимодействия цинксодержащих наночастиц с малеиновыми группами малеинизированного полиэтилена. Показано, что нанокомпозиты на основе полиэтилена могут перерабатываться как методом прессования так и методами литья под давлением и экструзией, что расширяет сферы его применения.

Ключевые слова: полиэтилен, иинксодержащие нанонаполнители, малеинизированный полиэтилен, физикомеханические свойства, рентгенофазовый и термографический анализы. 